\title{
Body and Tradition in Nineteenth-Century France: Félix Arnaudin and the Moorlands of Gascony,
}

1870-1914, by William G. Pooley, Oxford, Oxford University Press, 2019. 195 pp., $£ 60$ (hardback), ISBN 978-0-19-884750-2.

In this short book William Pooley invites the reader on an imaginative journey through the moorlands of Gascony, to meet the inhabitants and to contemplate the terrain and horizon, in the company of a unique guide. Simon Arnaudin, known as Félix (1844-1921), was the son of bourgeois parents and born in the village of Labouheyre. Following three years of secondary schooling in Montde-Marsan, Arnaudin pursued a solitary studious existence, confining his interests 'to a relatively small geographical area in order to produce better work' (p. 39). His unlimited ambition, to collect the folklore of his native territory (pays) known as the 'Grande Lande', resulted in a project that researchers would later judge impossible to complete.

Arnaudin's perception of himself as a 'collector' is significant for comprehending the nature of this personal project. It was a passion for collecting that drove him. The resulting archive reflects the idiosyncracies of the collector, as well as his extraordinary persistence in fieldwork that placed him 'at the mercy of weather, train timetables, and bicycles' (p. 47). Arnaudin, as the producer of an archive through his research, relied upon the services of informants. These singers and storytellers were active agents in the formation of his folklore collection, because through their co-operation, obfuscation, or error they could advance or hinder Arnaudin's progress. The notes, diary, and natural history writings of the folklorist were deposited in the Archives départementales des Landes de Gascogne in 1991.

Pooley's skills in mining Arnaudin's archive are coupled with the necessary empathy and historical imagination to enter into the folklorist's world, while retaining a critical detachment in order to study its intricate workings. Chapters 1 to 3 delve into the 'exchanges of money, objects, work, affection, and distrust' (p. 47) which were central to Arnaudin's daily life of compiling and recording. Pooley analyses the methods employed in this fieldwork but does not cast judgement on 
behaviours that, in hindsight, appear problematic. The result is a sensitive portrayal of Arnaudin's foibles, as well as achievements, that are appropriately placed in historical context.

What do we learn about 'body' and 'tradition' from Pooley's study of Arnaudin? These two words in the book's title refer to interrelated thematic interests that inform the structure. Every chapter is packed with a wealth of insights that are likely to interest social and cultural historians. Chapter 4 'Body Talk' advances a convincing argument about working people's ways of communicating a 'sexual toponymy of the body' (p. 77). Certain body parts were especially attributed with sexual meaning - the legs and feet being at the top of the list - and common metaphors used in description came from agricultural tools or household implements ('the frying pan of the knee' was the kneecap). Sexual organs, as well as sexual functions such as menstruation, were referred to by euphemism; one had to be in the 'know', otherwise the terminology made little sense. Pooley explains carefully how his argument contradicts the conclusions reached by Anne-Marie Sohn in her research on sexual education in nineteenth-century France. Sohn relied a lot on judicial sources that tend to produce a view of popular ignorance about sex, not least because defendents were protesting their own innocence in court trials. Far from reflecting a lack of knowledge among the workers of Gascony, the majority of Arnaudin's singers and storytellers communicated 'a free play of rude and fertile images' (p. 76). Some of the bawdier songs had obsence connotations that left the folklorist perplexed about whether it was appropriate to publish them, and how.

Pooley reveals how gender was implicated in the maintenance of traditions, as well as their evolution. He engages in the exacting task of reconstructing the socio-economic backgrounds of informants, gleaning as much information as possible about these men and women from public archival records such as marriage certificates and title deeds for property. Chapter 5 'Monstrous Bodies' explains how the emphasis that a singer or storyteller placed on an aspect of human relationships elaborated within folklore could result from their own life experience. A comparison of tales about werewolves recounted by two different women, Mariane de Mariolan and Marichoun Lescarret, serves to illustrate this point. Chapter 6 'Singing Love' demonstrates the ways in which 
popular songs about affection and passion were influenced by 'upheavals in local society' (p. 110). Working women preferred to sing about making love in the carefree spirit that they associated with pre-marital life, rather than about conjugal sexuality. Chapter 7 'Silence and Chastity' presents a moving portrait of Catherine Gentes, a seamstress who walked with a limp. Catherine determined which subjects she wished to sing about to the folklorist - in part, Pooley argues, because of her profession and her physical disability. Chapter 8 'Exploited Bodies' explores the complexity of tales about foxes and donkeys, especially their subtle meanings for sharecroppers and artisans.

Some of the upheavals that Pooley discusses were connected with changes in the physical environment of the moorlands as pine trees were planted for commercial forestry. Slower transformations were taking place in the social environment, notably in people's patterns of speech as Gascon words were replaced by what Arnaudin called 'gallicisms', a process that had being going on since the fifteenth century. In the Grande Lande, as in other parts of rural France prior to 1914, most people experienced bilingual communication in local dialect (patois) and the French language. Attitudes toward Catholicism were evolving. Arnaudin recorded an anecdote of locals making do without priests during the French Revolution; instead of receiving the sacrament of pardon, they 'used to confess to an old chestnut tree' (p. 136). The knowledge of rural working people was shared only on their own terms.

Elizabeth C. Macknight (e.macknight@abdn.ac.uk) is Senior Lecturer in European history at King's College University of Aberdeen and a Scottish Crucible alumna of the Royal Society of Edinburgh. She was educated in Australia and France. 